EX-HTI STRUGGLE IN PASURUAN:

\title{
Reading the Pattern of Changes in the Strategy of the Ex-HTI Da'wah Struggle
}

\author{
Bakhrul Ulum
}

Progam Doktoral UIN Sunan Ampel Surabaya, Jawa Timur email: bakhrululum76@gmail.com

Abstract: This paper discusses the pattern of changes in the ex-HTI da'wah strategy, which describes the process of exHTI struggle patterns in Pasuruan. This research is described qualitatively with a descriptive-analytical field study approach and data analysis techniques with the stages of data condensation, data display, and conclusion/verifying. The results of this study indicate that the ex-HTI da'wah struggle in Pasuruan continues to socialize the caliphate da'wah by utilizing digital media during the Covid-19 pandemic by utilizing elders as religious leaders, besides the pattern of changing its da'wah strategy by utilizing majelis taklim, "rumah inspirasi", Bustanul Amilin institution, and also SDIT.

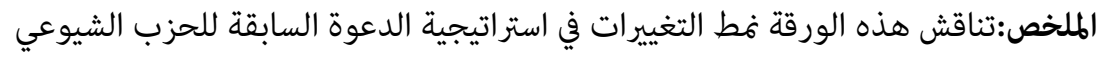

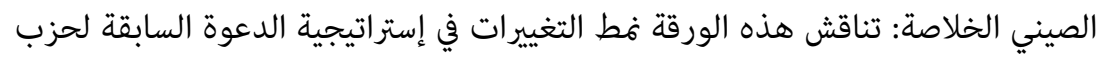

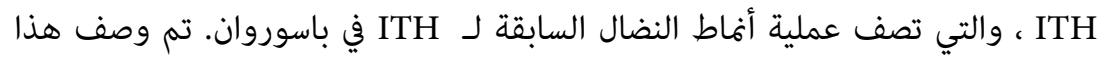

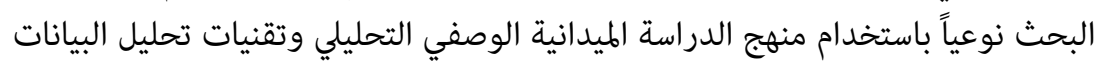

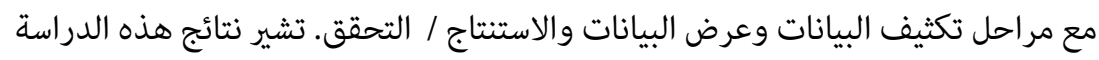

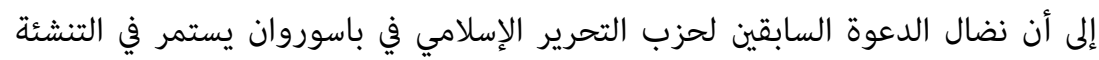

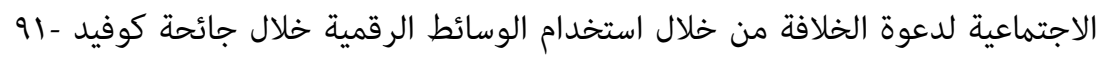

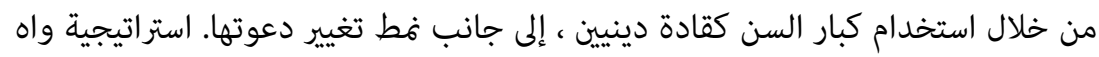

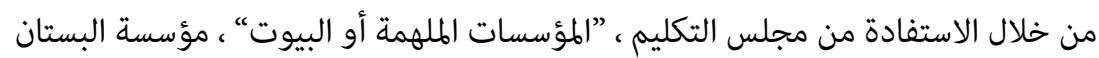

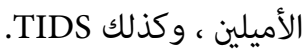

Abstrak: Tulisan ini membahas pola perubahan strategi dakwah eks-HTI yang tujuannya menggambarkan proses pola 
perjuangan eks-HTI di Pasuruan. Penelitian ini dijelaskan secara kualitatif dengan pendekatan studi lapangan secara deskriptifanalisis, dan Teknik analisis data dengan tahapan kondensasi data (data condentation), penjelas data (display data), dan kesimpulan/verifikasi (conclusion/verifying). Hasil penelitian ini menunjukkan bahwa pola perjuangan eks-HTI masih terus berlanjut, seperti perjuangan dakwah eks-HTI di Pasuruan tetap mensosialisasikan dakwah khilafah dengan pemanfaatan media digital di masa pandemi Covid-19 dengan memanfaatkan para sepuh sebagai tokoh agama, selain itu pola perubahan strategi dakwahnya dengan memanfaatkan majelis taklim, "lembaga atau rumah inspirasi”, lembaga Bustanul Amilin, dan termasuk juga SDIT.

Keywords: ex-HTI, da'wah, struggle strategy, majlis taklim, Pasuruan.

\section{INTRODUCTION}

The existence and struggle of HTI are still carried out by its followers and sympathizers in several parts of Indonesia, such as in Pasuruan, East Java, by using the Al-Hamidy Al-Islamiyah Foundation in Kalisat Village, Rembang District, which is the place for halaqah. Then, the bulletins, calendars, and the flag of Hizb al-Tahrir Indonesia (HTI) were found inside of the pesantren. ${ }^{1}$ From this, it can be seen that the pattern of HTI's strategy changes began to appear after the formal legal dissolution. In addition, within the Foundation, there are photos of President Joko Widodo scribbled on and photos of the current Vice President Jusuf Kalla, not Ma'ruf Amin, who is now in the office. This is fascinating to investigate the struggle of ex-HTI in Pasuruan. Furthermore, it is important to investigate how the existence of HTI in Indonesia is widespread, especially in Pasuruan.

Many kinds of research on HTI have been carried out, both from the ideology, movement, and others. After the formal legal dissolution of HTI, the HTI movement is still active, and its influence is growing. Among the research on the existence of HTI after the

1 Reporter Rizky Suryarandika, GP Ansor Teruskan Proses Hukum Terduga Pengikut HTI Pasuruan ”, pada hari Kamis, 27 Agustus 2020, dalam https://m.republika. co.id/amp/qfpudz396, di akses pada tanggal 26 Juni 2021, pukul 18:54. 
disbandment from the perspective of its struggle strategy there was a research which was conducted by Siti Nur Fitriyana. She discussed the existence of ex-HTI in several media that she controlled under the name of the Liberation Movement/Gerakan Pembebasan (GP), Back to Muslim Identity (BMI), and Muslimah News Id, Active, massive, and structured. ${ }^{2}$

Furthermore, a research report conducted by Nur Hasan and Mochamad Parmudi stated that after the formal legal dissolution of HTI, the movement seemed to be increasingly massive through online and intense media, then infiltrated various socio-political organizations and entered into religious da'wah activities carried out by other groups. ${ }^{3}$ Another research done by Ahmad Siddiq Abdurrahman, showed that the government's disbandment did not affect much. On the contrary, social media could still be used to spread the idea of a caliphate, such as the "Dakwah Sulsel" fan page, which is suspected to be a medium ridden by HTI cadres. ${ }^{4}$

In addition to the research mentioned before, there are many more studies on similar themes about ex-HTI, both da'wah strategies, struggle strategies, political strategies, and others. This means that research on HTI has been carried out many times. However, the researcher looks more at the pattern of the ex-HTI struggle in Pasuruan. In this context, I explain the pattern of changing the strategy of the ex-HTI da'wah struggle. The aim is to provide an overview of the ex-HTI da'wah struggle in Pasuruan. Researchers use the theory of da'wah strategy because with this da'wah, they can then show several possible strategies for developing various methods and models of Islamic da'wah, especially with a cultural da'wah approach that sees religion and culture sitting side by side. ${ }^{5}$

2 Siti Nur Fitriayana, "Fenomena Dakwah Eks-HTI Pasca Di Bubarkan," Islamic Comunication Journal 2, no. 2 (2019): 197-211.

3 Nur Hasan and Mochammad Parmudi, "Gerakan Sosial Keagamaan Dan Agenda Politik Kelompok Radikal Pasca Pemberlakuan Perpu No 2 Tahun 2017 Tentang Organisasi Masyarakat: Studi Kasus Hizbut Tahrir (HTI)” (Semarang, 2018), 5-134.

4 Ahmad Siddiq Abdurrahman, "Strategi HTI Di Kota Makassar Pasca Pembubaran Oleh Pemerintah" (Universitas Islam Negeri Alauddin, 2019).

5 Afidatul Asmar, "Genealogi Dan Strategi Dakwah Kultural NU," Islamica: Jurnal Studi Keislaman 13, no. 1 (2018): 169, https://doi.org/10.15642./ islamica.2018.13.1.164-183. 
In explaining the theme qualitatively, the researcher uses a literature study and field study approach. For the literature study, the researcher collected several themes related to this research, namely to see the development of the research that has been done so far. The field of the study was used because it involved the locus of research that I did in Pasuruan, but this research was carried out in Kalisat Village, Rembang District, in more detail. This is done to meet the criteria of this research variable related to the pattern of ex-HTI struggle starting from an explanation of HTI between Islam and the State, HTI propaganda strategies, and ex-HTI struggle strategies Pasuruan.

The analysis technique used is descriptive analysis; this is done in several stages with data condensation, data display, and conclusion: drawing/verifying. ${ }^{6}$ I was inspired by the use of this analysis by Ali Akhbar Abaib's research on Islamic education during the Indonesian Umayyad period because in the analysis stage, the research is explained, in the form of: 1) data condensation is more about the research process by selecting data that matches the theme, then simplifies it descriptive and abstract, after that, it is densely transformed from several data sources as needed, 2) data explanatory or data exposure is data that has been collected and compressed, then the conclusion of the message is drawn, 3) the conclusion of the message is then verified to replicate the findings or provide a valid explanation. Engaging about what is described in the data description, then form an interactive and cyclical process. $^{7}$

\section{HTI: ON ISLAM AND THE STATE}

Hizbut Tahrir Indonesia (HTI) is one of the organizations that is banned in Indonesia. It's because it does not have a juridical basis in its re-establishment which can be seen in the existence of Law Number 16 of 2017 concerning Community Organizations (from now on referred to as Law No. 16 of 2017 concerning Community Organization). Like several points that can be underlined regarding mass organizations being prohibited from "carrying out hostile acts

${ }^{6}$ Matthews B. Milles, A. Michael Huberman, and Jhonny Saldana, Qualitative Data Analysis: A Methods Sourcebook, 3rd ed. (Los Angeles, London, New Delhi, Singapore, Washington DC: Sage, 2014).

7 Ali Akhbar Abaib Mas Rabbani Lubis, "Pendidikan Islam Masa Umayyah Dan Indonesia: Seputar Perkembangan, Penggambaran, Dan Implementasi Pendidikan Islam Di Indonesia," Medina-Te: Journal Studi Islam 16, no. 1 (2020): 46-47. 
against ethnic groups, religions, races, and groups" this action is also clarified by "performing acts of violence, disturbing peace and public order, or damaging public facilities and social facilities.", from actions that disturb the peace and public order are extorted such as "carrying out separatist activities that threaten the sovereignty of the Unitary State of the Republic of Indonesia and/or ideas that are contrary to Pancasila". 8

There are various exciting views in looking at the pattern of changes in the strategy of the ex-HTI struggle in launching their da'wah. However, before reviewing this, the researcher briefly discusses the relationship between Islam and democracy when faced with HTI, such as research conducted by Ali Maksum, in which it discusses the relationship between Islam and democracy in the view of the Liberal Islam Network (JIL) and Hizb ut-Tahrir Indonesia (HTI). His research was utilizing Critical Discourse Analysis (CDA) and sees that JIL is very much in line with the view that Islam is compatible with democratic values. On the other hand, HTI disagrees with Islam which is in line with democracy because democracy comes from a capitalist and secular western culture. Furthermore, Ali Maksum saw that these differences were motivated by education, derivation of knowledge, and global political conditions. ${ }^{9}$

His disagreement with democracy demands that HTI's da'wah strategy is mapped out by discussing HTI's line of thought and political movements. On one hand, Fisher Zulkarnain has discussed this in his research; his interest is to see that the Government of Indonesia, with its policies that gave birth to Law No. 16 of 2017 concerning Community Organization, considers that HTI can threaten the future of Indonesian democracy. The caliphate movement offered by HTI received a significant response, both in da'wah activities and mass mobilization. On the other hand, the Indonesian government

8 Law Number 16 of 2017 concerning the Stipulation of Government Regulation instead of Law Number 2 of 2017 concerning Amendments to Law Number 17 of 2013 concerning Community Organizations into Law, Article 59 paragraph (3) points a, c, paragraph (4) points b, c.

9 Ali Maksum, "Discourses on Islam and Democracy in Indonesia: A Study on the Intellectual Debate between Liberal Islam Network (JIL) and Hizbut Tahrir Indonesia (HTI)," Journal of Indonesian Islam 11, no. 2 (2017): 405-22, https://doi. org/10.15642/JIIS.2017.11.2.405-422. 
considered the khilafah concept promoted by HTI to be very contrary to the constitution in Indonesia. ${ }^{10}$

A significant response to the strategy of the HTI da'wah movement in da'wah activities and mass mobilization demands that the government immediately make a policy to disband the organization. As the research conducted by Ayu Rizka that the dissolution of HTI on July 19, 2017, is a form of securitization of the Indonesian government, such as 1) the concept of the highest state is still a reference in national security dialogue because the security building is still under the responsibility of the military, 2) international bias on the dissolution of HTI in several countries such as Jordan, Egypt, Syria, Saudi Arabia, and others, 3) the notion of "Indonesia is Second Syria", 4) the historical reality of Pancasila and anti-Pancasila carried out by the Indonesian government, 5) the state's unfriendliness in viewing the idea deconstruction is considered a threat to the Unitary State of the Republic of Indonesia and Pancasila and ignores the value of political imagination about the good of humanity in the future, and 6) HTI securitization was first carried out by non-state actors, such as Nahdlatul Ulama (NU) and continued by state actors through the Ministry of Law and Rights. Human Rights (Kemenkumham). However, Ayu Rizka emphasized that the Indonesian government should establish two-way communication with groups that have different ideologies and provide solutions to their criticisms of Indonesia's condition in the future. ${ }^{11}$

Siti Muazaroh's reason for the government's disbandment was that the Indonesian government's efforts to disband HTI were not meant as an anti-Islamic organization but for the sake of the unity and peace of the nation's children. In his research that uses a maqashid perspective that departs from Khaled Abu Fadl's theory that the considerations of maslahah and mafsadat on the dissolution of HTI by Siti Muazaroh, namely: first, from related maslahah, 1) maintaining the integrity of the Republic of Indonesia, 2) preventing radicalism and various other violence, and 3) protect the country which is in a critical

${ }^{10}$ Fisher Zulkarnain, "The Political Thought and Movement of Hizbut Tahrir Indonesia (HTI)," Journal of Critical Reviews 7, no. 1 (2020): 478-82, https://doi. org/10.31838/jcr.07.01.94.

${ }^{11}$ Ayu Rizka, "The Securitization of Hizbut Tahrir Indonesia," Politik Indonesia: Indonesian Political Science 5, no. 2 (2020): 172-91, https://doi.org/10.15294/ipsr/ v5i2.21712. 
condition through the PERPU which later became law. Second, from the related mafsadat, 1 ) eroding the transparent value of democracy, 2) overriding the judicial process, and 3) reducing the existence of the Constitutional Court (MK) as the examiner of PERPU. If this is a threat to the Unitary State of the Republic of Indonesia, then it cannot be linked to HTI alone, but several other covert organizations may be far more dangerous. It is just that the government authorities have carried out the right policy because part of the commitment contained in the Nawacita and its decisions have silenced one face of the organization. ${ }^{12}$

\section{HTI: DA'WAH STRATEGY}

To review a little about the background of Hizb al-Tahrir, Hizb alTahrir has applied for permission to the Jordanian government through the Ministry of Home Affairs as a political party. Then the effort was rejected, and its existence as an organization was considered illegal. From here, Hizb al-Tahrir was officially established in Palestine, and its influence is getting more robust due to concerns over the decline of Muslims. Therefore, Hizb al-Tahrir was established to restore the glory of Islam employing da'wah and jihad; this achievement must be with the establishment of an Islamic government based on Islamic teachings sources such as the Qur'an and Sunnah in the face of the Islamic caliphate. ${ }^{13}$

Hizb al-Tahrir in Indonesia, which has now become Hizb alTahrir Indonesia (HTI), started with the interaction of Kyai Abdullah bin Nuh, owner of the al-Ghazali Islamic Boarding School in Bogor and invited Abdurrahman al-Baghdadi (a Hizb al-Tahrir activist) who lived in Bogor around 1982-1983. Then from there, HTI began to gain the influence. In addition to utilizing public campuses (such as IPB Bogor) and young campus mosque activists, he further developed his movement by joining the Campus Da'wah Institute (LDK) and spreading it to many other public campuses. From here, its development was relatively fast and gained many followers who

${ }^{12}$ Siti Muazaroh, "Pembubaran Hizbut Tahrir Indonesia (HTI) Perspektif Maqashid: Otoritas Atau Otoritarianisme," Justicia Islamica: Jurnal Kajian Hukum Dan Sosial 16, no. 1 (2019): 103-20, https://doi.org/10.21154/justicia.v16i1.1622.

${ }^{13}$ Hasan and Parmudi, "Gerakan Sosial Keagamaan Dan Agenda Politik Kelompok Radikal Pasca Pemberlakuan Perpu No 2 Tahun 2017 Tentang Organisasi Masyarakat: Studi Kasus Hizbut Tahrir (HTI),” 25-26. 
spread to various regions in Indonesia. ${ }^{14}$ HTI also held International Khilafah meetings on 28 May 2000 and 12 August 2007 and even wrote an open letter to President Susilo Bambang Yudiono to offer a caliphate in Indonesia. HTI is actively criticizing government policies that deviate from Islamic teachings and offering political agendas with an Islamic system. ${ }^{15}$ However, on its way, it was disbanded in 2017.

The organizational disbandment of HTI was carried out four years ago through Government Regulation instead of Law (Perpu) No. 2 of 2017 concerning community organization (now Law No. 16 concerning Community Organization), but HTI's struggle has not subsided and has not died because of its influence in the society. Even though the Indonesian government considers them a separatist association that threatens the Unitary State of the Republic of Indonesia or contradicts Pancasila, HTI sympathizers are still exist. As the case in Kalisat Village, Rembang District, there was an AlHamidy Al-Islamiyah Foundation, a halaqah place for HTI cadres, in August 2020. ${ }^{16}$ This means that the existence of ex-HTI can still be detected even though they do not use an organization called HTI, but their movement uses other organizations to develop their da'wah and ideology, as mentioned above with a foundation legal entity.

To review about the political struggle of HTI in general terms can be seen in the research conducted by Ana Sabhana Azmy, which discusses more on the political thought of HTI as a movement of Islamic fundamentalism in Indonesia. ${ }^{17}$ His research looks more at HTI's work in political phenomena in Indonesia and the concept of political awareness according to HTI adherents, including: first, democracy in HTI's view is an infidel system because the West socializes it, so it has no connection or is in line with Islam. ${ }^{18}$

${ }^{14}$ Hasan and Parmudi, 27-28.

${ }^{15}$ Ana Sabhana Azmy, "Fundamentalisme Islam: Telaah Terhadap Pemikiran Politik Hizbut Tahrir Indonesia (HTI),” Jurnal Wacana Politik 5, no. 1 (2020): 91-97, https://doi.org/10.24198/jwp.v5i1.27997.

${ }^{16}$ Adi Briantika, Ansor-Banser Gruduk HTI di Pasuruan dan Keduanya Samasama Keliru, pada hari Senin, 26 Agustus 2020. in https://amp.tirto.id/ansor-bansergruduk-hti-di-pasuruan-dan-keduanya- sama-sama-keliru-flhC, accessed on 27 Juny 2021, at 14:59.

${ }^{17}$ Azmy, "Fundamentalisme Islam: Telaah Terhadap Pemikiran Politik Hizbut Tahrir Indonesia (HTI)," 88.

${ }^{18}$ Azmy, 91-92. 
There are six things that the researcher finds attractive in Ana Sabhana Azmy's explanation of HTI's political views that are different from western democracy, as explained by Ismail Yusanto, namely: 1) sovereignty, namely Islam views power as being in the hands of Allah, so that power is not in the hands of humans. 2) power is in the hands of the people, meaning that in Muslim society, there is no ruler until the people want it through the appointment and not to become rulers, but to carry out Islamic law, meaning not to exercise people's sovereignty. 3) Human Rights: There is no compulsion to convert to Islam, but one cannot leave Islam at will because apostasy is punished by carrying out a procession of appropriate punishment for apostates. 4) decision-making, meaning that deliberation is not everything in making decisions because some things cannot be discussed, such as faith and the Shari'a. 5) the power of the leader (caliphate), who leads the community, is the figure of the caliph with an election mechanism and is appointed by the people, jester the distribution of power in the concept of democracy not in line with Islam. 6) The ummah/shura assembly is the representative of the ummah who is elected to express the opinion of the ummah, not a kind of legislative body because it does not stipulate the law. ${ }^{19}$

Second, the khilafah struggle is the central concept in the HTI struggle and must be implemented by the Muslim community so that the khilafah is based more on religion while democracy is based more on the people's provisions. ${ }^{20}$

Third, HTI's work in politics in Indonesia, such as in 2010 distributing bulletins published by HTI in the "Al-Islam Bulletin" regarding human rights issues, America versus Muslims, Indonesianness, labelling things as haram and the urgency of the establishment of the khilafah. HTI also held International khilafah meetings on 28 May 2000 and 12 August 2007 and even wrote an open letter to President Susilo Bambang Yudiono to offer a caliphate in Indonesia. HTI is actively criticizing government policies that deviate from Islamic teachings and offering political agendas with an Islamic system. ${ }^{21}$
${ }^{19}$ Azmy, 91.
${ }^{20}$ Azmy, 93-95.
${ }^{21}$ Azmy, 95-97. 
During the New Order era as a clandestine organization, Masdar Hilmy, in his research, provides some further analysis of HTI's ideology that at that time HTI published the weekly Al-Islam magazine, in which the magazine spoke about contemporary socio-political discourse whose contents refer more to analysis sourced from the Qur'an and Hadith. As in 1993, five thousand copies of the magazine were published in all mosques in Indonesia through a network of activists or HTI cadres. Al-Islam magazine is effortless to understand (popular writing), which is then very much accepted by Muslims in Indonesia, then developed in $2000 \mathrm{Al}-\mathrm{Wa}$ 'ie magazine which is a magazine other than Al-Islam. Al-Wa'ie magazine contains topics relevant to middleclass Muslims: questions and answers, muhasabah, focus, analysis, afkar, criticism, hiwar, interpretation, siyasah-da'wah ta'rifat, book study, the Islamic world, and exemplary. Since the first caliphate conference was held in August 2000 at the Senayan Jakarta Stadium, which many as five thousand activists attended, HTI has influenced its comprehensive coverage. This was initially only an elite-based bottom movement but became a relatively large mass organization and subsequently carried out activities openly and campaigning for the ideology of applying Islamic law in Indonesia and the rise of the caliphate. $^{22}$

The campaign regarding the ideology of applying Islamic law and the rise of the caliphate in Indonesia has been researched by Ali Akhbar Abaib Mas Rabbani Lubis. His research explains that his struggle through political strategy is part of Indonesia's historical cycle of independence. ${ }^{23}$ Then in another study that looks more at the relevance of al-Jabiri's thinking that relates it to a touch of political phenomena in Indonesia since 2016-2019, namely the friction between the Pancasila ideology regarding the Unitary State of the Republic of Indonesia and the struggle to create an Islamic state legally-formally by introducing "NKRI Bersyari'ah". The hot topic was related to

${ }^{22}$ Masdar Hilmy, "The Rise and Fall of 'Transnational' Islam in Indonesia: The Future of Hizbut Tahrir Indonesia (HTI)," in Rising Islamic Conservatism in Indonesia: Islamic Groups and Identity Politics, ed. Leonard C. Sebastian, Syafiq Hasyim, and Alexander R. Arifianto (London, New York: Routledge, 2021), 137.

${ }^{23}$ Ali Akhbar Abaib Mas Rabbani Lubis, "Contestation On Political Space Between Islamism and Islamic Group in Presidential Election 2019," Al-Tahrir: Jurnal Pemikiran Islam 20, no. 2 (2020): 205-29, https://doi.org/10.21154/altahrir. v20i2.1932. 
the emergence of the basic pattern of qabilah with the presence of FPI and HTI forces in the same space. This basic pattern of aqidah was implemented with the symbol term "NKRI Bersyari'ah", the ideological discourse of the caliphate, "Big Imam", demonstrations "Defend Islam", and contestation (such as the struggle for space for ideological and political domination). Furthermore, the basic pattern of this ghanimah with social climbing, such as discussing the 1945 Constitution and the Presidential Decree of Soekarno in 1959 as a reason to ratify the "NKRI Bersyari'ah", even criticizing that the Indonesian state as an "infidel" country and the caliphate is the solution, from Here there is a bargaining position among the political elite. ${ }^{24}$

The HTI organization fights for Islam by considering politics as its movement and Islam as its ideology. The pattern of his movement is seen in tabligh akbar activities and demonstrations to convey his ideas in the public sphere.

This da'wah struggle is also known as the struggle for space (Indonesia); the effort and the extent to which this dynamic takes place are examined by Ali Akhbar Abaib, who see that there are similarities in the movement in achieving its goals, namely the establishment of an Islamic government, such as HTI which fighting for the caliphate, joined in a group that took part in the struggle for "NKRI Bersyari' ah" which M. Rizieq Shihab first introduced. This means that the struggle to achieve the implementation of shari'a was not born out of a space or suddenly, but instead was born from a long history of debates between groups fighting for an Islamic state and groups fighting for the Unitary State of the Republic of Indonesia when Indonesia became independent. However, it should be realized that the Unitary State of the Republic of Indonesia is the consensus of the founding fathers of the nation that must be maintained, so that the "NKRI Bersyari'ah" or those in which there is a secret mission such as the HTI movement that fights for the caliphate, needs to be reconsidered because it can damage the unity of the country, especially since the Unitary Republic of Indonesia is adherents of there is not only one religion and those who fight for the Unitary State of the Republic of Indonesia are also

${ }^{24}$ Ali Akhbar Abaib Mas Rabbani Lubis, "Rethinking the Book of Al-'Aql AlSiyasi Al-'Arabi and Indonesian Political Phenomenon," Jurnal Penelitian 17, no. 1 (2020): 67-80, https://doi.org/10.28918/jupe.v17i1.2767. 
ulama and Islamic activists. For this reason, the Republic of Indonesia also does not need to add to the nomenclature of "shari' ah" because Indonesia has accommodated Islamic demands. ${ }^{25}$

HTI's struggle did not stop just because the Indonesian government revoked the organization's legal status. This is because thousands of HTI members embrace a strong resistance strategy. It is as explained in Inayah Rohmaniyah's research, which examines the effectiveness of government efforts and their impact on the sustainability and discontinuity of the HTI movement which was explored from a field study in Gorontalo in 2018. The results of his research indicate that the revocation of the organization's legal status has encouraged HTI activists to carry out symbolic resistance through the gap between religious circles on campus and in villages by utilizing various socio-religious activities in the community and door to door visits. The community still accepts the pattern of struggle because of the narrative that Islam and the five daily prayers bring about; even the maintenance of HTI ideology and its idealistic pattern is carried out through integration or transformation into other organizations or communities. From there, they enter and apply HTI's ideas and ideology and implement them in their daily lives. ${ }^{26}$

HTI regeneration system is usually called halaqah. This regeneration system is a study group that forms a circular pattern. This way, the unit is seen as a medium of indoctrination as research conducted by Siti Aisyah explained that halaqah is a small unit of new members in the cadre to study HTI ideology in depth under the guidance of experienced seniors. This halaqah activity consists of approximately five new cadres who circle the supervisor or senior, usually called the coach. This activity lasts approximately two hours; this halaqah is also referred to as a method of da'wah with the term tatsqif. This process not only continues around the study but is also

${ }^{25}$ Ali Akhbar Abaib Mas Rabbani Lubis, "NKRI Bersyariah: Praktik Spasial, Representasi Ruang, Ruang Representasional," Al-Daulah: Jurnal Hukum Dan Perundangan Islam 10, no. 2 (2020): 222-50, https://doi.org/10.15642/ ad.2020.10.2.222-250.

${ }^{26}$ Inayah Rohmaniyah, "The Perpetuation of Identity and Symbolic Resistance of Hizbut Tahrir Indonesia After the Official Disbandment in 2017," Islamica: Jurnal Studi Keislaman 15, no. 2 (2021): 159-94, https://doi.org/10.15642/ islamica.2021.15.2.159-194. 
directly practised in everyday life by being monitored by the supervisor to keep it by the interpretation pattern set by HT. ${ }^{27}$

According to Muhammad Diak Udin and Abdul Muhid, the halaqah regeneration system is inseparable from the communication method used. The word of mouth communication model with a personal approach is also known as word of mouth communication. That is, a communication that is chained and develops by itself in specific communities that are applied in two activities, such as 1) the method of delivering da'wah, both conventionally and electronically, 2) the cadre method, the stages of which are delivered in a chain to official cadres based on the HTI curriculum or study book. Some of the factors in using this word-of-mouth communication are to ensure close relationships, warmth, psychologically being able to respond directly, trust, sincerity, authenticity and others. Another factor is the social culture in Indonesia, which is already friendly and open about information. ${ }^{28}$

The above explanation shows that by what is meant by Muhammad Sabri's research, Muh. Ikhsan, and Ismail Suardi Wekke, namely that HTI is a social movement that can be identified with three categories, such as 1) HTI is a specific movement that wants to implement Islamic law as a whole with the islamic khilafah system, 2) HTI is also called a radical movement that wants to implement the Islamic khilafah system. "Islam" in life, 3) HTI seeks to restore the Islamic order as the centre of world civilization. However, his research reveals that HTI in its movement has never used a violent approach. ${ }^{29}$

It is interesting to mention Inayah Rohmaniyah's discussion in her research, which discusses the sustainability of radical ideologies, especially her research in Gorontalo regarding depersonalization and women's agency after the disbandment of the HTI organization. However, it has weakened group identity and depersonalization, but

${ }^{27}$ Siti Aisyah, "Halaqah: Media Komunikasi, Publikasi Eksistensi Hizbut Tahrir Indonesia Sebelum Dan Pasca Pembubaran," Asyahid Journal Od Islamic and Quranic Studies (AJIQS) 1, no. 1 (2019): 10-11.

${ }^{28}$ Muhammad Diak Udin and Abdul Muhid, "Komunikasi Getok Tular Dan Metode Dakwah Hizbut Tahrir Indonesia,” Jurnal Komunikasi Islam 8, no. 2 (2018): 139-274, https://doi.org/10.15642/jki.2018.8.2.239-274.

${ }^{29}$ Muhammad Sabri, Muh. Ikhsan, and Ismail Suardi Wekke, "Gejala Fundamentalisme Agama Di Indonesia: Membaca Hizbut Tahrir Indonesia Sebagai Gerakan Sosial," INA-Rxiv 14 (2017), https://doi.org/10.31227/osf.io/a4mp7. 
she mentions that the dissolution not only weakens group identity and depersonalization of ex-HTI cadres. From there, the former HTI shifted the da'wah space from a public space to limited space, from targeting large groups to the individual realm (door to door), utilizing friendship and brotherhood networks, and placing women's roles more significantly. ${ }^{30}$ Although psychologically, the HTI cadres are shocked and depressed about the government's policy regarding its dissolution as a legal entity, HTI cadres are persistent in preaching the caliphate on behalf of other organizations such as the Indonesian Community Without Dating, Yuk Ngaji, Fast Hijrah, Cinta Nabi Cinta Syari'ah Council. Imitation of the Life of the Prophet. This organization is significant because it is supported by figures who are always active in campaigning for the caliphate da'wah, such as Ismail Yusanto, Felix Siaw, Laode Munafar, and others who display a style or appearance that millennial young people readily accept.

\section{EX-HTI STRUGGLE STRATEGY IN PASURUAN}

The ex-HTI Pasuruan became the starting point for this research because on August $20^{\text {th }} 2020$ ago, Sa'ad Muafi as Chairman of the Branch Management of the Ansor Youth Movement, along with hundreds of members from the organization, visited one of the houses considered to be followers of HTI; specifically, Kalisat Village, Rembang District, Pasuruan Regency. Then after that, he visited the Educational Institution of the Al-Hamidy Al-Islamiyah Foundation in the same village. This was triggered by a post allegedly harassing one of the NU figures, namely al-Habib Muhammad Luthfi bin Ali bin Yahya (called Habib Luthfi); the post also contained a statement that the rejection of the caliphate, which was part of Islamic teachings, was due to stomach problems. Even this Ansor organization found HTI flags and several sheets related to HTI; even this educational institution was also said to be a "nest" for HTI sympathizers to gather. ${ }^{31}$

\footnotetext{
${ }^{30}$ Inayah Rohmaniyah, "Perpetuation of Radical Ideology: Depersonalization and Agency of Women After the Banning of Hizbut Tahrir Indonesia," Al-A'raf: Jurnal Pemikiran Islam Dan Filsafat 17, no. 1 (2020): 45-66, https://doi.org/10.22515/ajpif. v17i1.2361.

${ }^{31}$ Fandi Armanto, Madrasah di Rembang Dilurug Banser, Diduga Jadi Tempat Kaderisasi HTI, 20 Agustus 2020, in https://radarbromo.jawapos.com/ headines/21/08/2020/madrasah-di-rembang-dilurug- banser-diduga-jadi-tempatkaderisasi-hti/amp/, accessed on 28 June 2021, at 19:24.
} 
HTI's struggle will always face tough challenges because only $\mathrm{NU}$ is the strongest against the caliphate ideology among moderate Islamic mass organisations..$^{32}$ The explanation above shows that NU's autonomous bodies (banom), namely GP Ansor (Gerakan Pemuda Ansor) and Banser (Barisan Ansor Serbaguna) are often involved in disbanding Islamic recitations. Scholars who support the khilafah. So, HTI needs to make a strategy or metamorphose in the da'wah pattern that is carried out so that the socialization of the caliphate ideology can be grounded in the community and widely accepted.

The pattern of HTI cadre after the disbandment in South Sulawesi, this research has been carried out by Essi Ramadanti and Hizbullah. The disbandment of HTI by government policies does not necessarily erase the ideological understanding of HTI cadres; according to him, it will be more complex and become an arduous task for the government because HTI will take advantage of other organizations that are in line with it and steal the opportunity to offer a caliphate ideology when there is no public satisfaction with the government or its policies. It can be seen, for example, that the implementation of HTI studies which are accommodated by the Campus Da'wah Institute (LDK) and pamphlets. The HTI cadre pattern in South Sulawesi is carried out intensively by instilling the application of sharia with a caliphate government system which is then disseminated to all elements of society so that these thoughts and ideologies continue to develop widely; the cadre pattern is carried out directly and indirectly by distributing pamphlets and da'wah. The search for new cadres is carried out in mosques, campuses, among lecturers, community leaders, religious leaders, taklim assemblies, and others through print and online media. ${ }^{33}$

The above illustrates that there was a pattern of changes in HTI's missionary struggle strategy after the disbandment, which is very difficult to identify because HTI cadres are now integrated and transformed into other communities. Some of the information was obtained from us. Syamsudin as the former chairman of the ex-HTI Pasuruan, for example, said that some activities were off before, but

${ }^{32}$ Hilmy, "The Rise and Fall of 'Transnational' Islam in Indonesia: The Future of Hizbut Tahrir Indonesia (HTI),” 142.

${ }^{33}$ Essi Ramadanti and Hisbullah, "Eksistensi Dan Pola Perkaderan Pasca Pembubaran Hizbut Tahrir Indonesia," Siyasatuna 2, no. 2 (2020): 351-62. 
the idea is still open, HTI's strategy in grounding the da'wah of Islam and the Khilafah in Pasuruan is the same as others, even "the whole world" is the same; namely, the socialization is da'wah. Caliphate is necessary. ${ }^{34}$ During the Covid-19 Pandemic, Ex-HTI used religious leaders such as elders to use Zoom media to preach about the caliphate; then, intense communication was still carried out through contact persons and WhatsApp media. Moreover, they use the Bustanul Amilin Institute, assemblies of taklim, "inspirational institutions/ houses", including SDIT as media to launch the caliphate $d a$ 'wah. The explanation of the opportunity for da'wah after the dissolution or revocation of the HTI organization's law and the challenges or obstacles can be explained in the next theme.

\section{EX-HTI DA'WAH PATTERNS IN PASURUAN}

The pattern of ex-HTI da'wah struggle in Pasuruan after the Covid-19 pandemic mainly was made online, except in village areas where taklim assemblies were usually directed to study at home or inspirational institutions. However, an essential thing in the pattern of da'wah, which is carried out as a form of socialization of the caliphate da'wah, namely contact persons, halaqah meetings, and others, is still carried out intensively and deeply. In fact, in their coaching, ex-HTI cadres are obliged to memorize twenty-three books in Arabic, and about half of these ex-HTI figures have been translated into Indonesian, which is almost $90 \%$ written by Taqiuddin al-Nabhani. Many HTI cadres memorized the book, but there are also only part of it and the memorized books, for example, Nidham al-Islam, Fikr al-Islam, Nidham al-Ihtishad, Al-Anwal li mudhat al-Khilafah, Sufism, Nafsiyah Islamiyah, which the next emir added as follows: development, Takhrij Hadith, Nidham Siyasi, Afkar Siyasi fi Ulumi Tahrir, Nahdur al-Siyasi fi Ulumi Tahrir, Sakhsiyah Islamiyah volume 3, and others. ${ }^{35}$

The dissemination of this da'wah is part of the mission of Islamic teachings in general, but in this strategy, the ideas of the caliphate are grounded in Pasuruan Ust. Syamsudin did not want the public only to know that the caliphate was only an external thing, then he explained:

"Usually, we don't want this community to only know about the caliphate, sir. For this reason, further socialization of the caliphate

\footnotetext{
${ }^{34}$ Interview, Ust. Syamsudin, on 27 June 2021.

${ }^{35}$ Interview, Ust. Syamsudin, on 27 June 2021.
} 
is necessary. In what way? by way of their cadre halaqah, sir. Yes, so, and until now, even though we have quoted quotes, yes, we have been disbanded, yes, it is still halaqah. It's impossible to be online, sir. Again, the online pandemic forced the elderly to be able to zoom. Besides halaqah, turba, asyrah, then what, if it's digital now, sir, the whatsapp app... and then now the discussions are amazing, we often have seminars, now it's easy to get money, until we are given two million". ${ }^{36}$

Some of the things that underlie the formation of the pattern of ex-HTI struggle in Pasuruan that have been described do not deny the opportunities and constraints for ex-HTI da'wah, so that this pattern of struggle can be illustrated as part of the dynamics that occurred after its disbandment.

\section{Ex-HTI Da'wah Opportunities in Pasuruan}

The explanation above shows that the existence and pattern of HTI cadre continues, and the enthusiasm for discussions about HTI's thoughts and ideology is extraordinary, especially during the Covid-19 Pandemic, which demands that religious leaders such as elders be able to use Zoom media to preach. Caliphate in various circles. This explanation is in line with Masdar Hilmy's argument when discussing the future of HTI, including:

"This means that the Perpu will have made HTI's activities as clandestine as they were under New Order regime. Its supporters may go back to business as usual, as lecturers, professionals, researchers, general practitioners, businessmen and other professionals. They can revive the transnational ideology easily should socio-political conditions make it necessary". ${ }^{37}$

At least his opinion regarding the revocation of the legal status of the HTI organization made its movement become clandestine or creep, such as being a lecturer, professor, researcher, general practitioner, businessman, and other professionals.

"So now the socialization is like that. Now it's even better, sir. In the industrial era 4.0, online-based education makes it easier for

\footnotetext{
${ }^{36}$ Interview, Ust. Syamsudin, on 27 June 2021.

${ }^{37}$ Hilmy, "The Rise and Fall of 'Transnational' Islam in Indonesia: The Future of Hizbut Tahrir Indonesia (HTI)," 142.
} 
us, sir. Even though online there is no eye contact, sir. If like this, there is eye contact. So, it's not necessarily accepted or anything, but in general it's massive, sir". 38

Furthermore, after it was disbanded, the HTI cadres were administratively orderly so there would be no more violent clashes, so they demanded to lie down first. However, the point is that HTI in Pasuruan and elsewhere is contact or continuous communication, either through contact persons, through Whatsapp and others. ${ }^{39}$ This kind of movement is easier to do and quite accepted because the community is enthusiastic and extraordinary to follow it. What is more, in the Rembang sub-district, the head of the HTI there is a village cleric; in fact, the majority are Madurese mixed Javanese Pandalungans whose obedience to the kyai is number one..$^{40} \mathrm{Next}$, Syamsudin emphasized:

"That's the difference like in Bangil and Pasuruan. In Bangil it is more person to person, one can get one or one can get one family. But in Rembang, if you get the kyai, you can get the students and the family too. Even though his family or students will have an attitude of refusal, it is certainly more conducive". ${ }^{41}$

It is generally accepted in any village; for example, HTI cadres get Kyai Pondok Alhamidi in Rembang, such as Kyai Zainullah Muslim. ${ }^{42}$ This shows that the pattern of ex-HTI struggle in Pasuruan, especially in Rembang, is not the least bit different from the others; namely, they are more active in preaching the caliphate directly to kyai in Islamic boarding schools or religious leaders in the village, so that the spread of HTI ideas and thoughts can be easily accepted among the community. Who incidentally is very obedient to the kyai.

Another opportunity and chance is that because energy is not too drained during the pandemic period after the dissolution or revocation of the legal status of the organization, the lesson is more on internal strengthening, both personally and organizationally. Even now, the community-based ones are still running well; for example, the Karawitan community (religious belief) accepts HTI's caliphate

\footnotetext{
${ }^{38}$ Interview, Ust. Syamsudin, on 27 June 2021.

${ }^{39}$ Interview, Ust. Syamsudin, on 27 June 2021.

${ }^{40}$ Interview, Ust. Syamsudin, on 27 June 2021.

${ }^{41}$ Interview, Ust. Syamsudin, on 27 June 2021.

${ }^{42}$ Interview, Ust. Syamsudin, on 27 June 2021.
} 
da'wah. As explained above, the HTI movement in other places such as the urban areas of Pasuruan and Bangil is more clandestine, in contrast to Rembang, which is entirely open because the majority are still ethnic Madurese groups because the kyai support HTI, even though in practice it is NU because HTI according to the view of its supporters is a political party or movements demanding the establishment of a caliphate. $^{43}$

\section{Obstacles to the Da'wah of ex-HTI in Pasuruan}

Apart from the opportunity for proselytizing ex-HTI after the disbandment, there are also obstacles in their struggle, namely legal consequences. At least this government policy requires HTI cadres to have a diaspora, as according to Ust. Syamsudin provided a coat (safety) using the Bustanul Amilin Institute at his residence; even the taklim assembly became a (closed) cell and felt under constant surveillance. ${ }^{44}$ Then from this diaspora demands for the caliphate da'wah, which was initially open, for example like the taklim assembly, into other activities that changed in the name of inspirational institutions/houses, educational institutions such as Islamic boarding schools, schools and others, which no longer used the flag, but more importantly the idea can be passed on. ${ }^{45}$

The general obstacle to the struggle of ex-HTI in Pasuruan is that when they are invited to kindness intensely, it is difficult. Inviting to do good is hard, especially then telling others to do well too. Another risk is dealing with rulers who have attributes such as weapons, police, and money. Then the risk of dealing with Structural NU, which always scares the people or "monasteries" HTI or the caliphate in terms of radicals and terrorists, with Banser who always attack. So that ex-HTI cadres respond only as necessary, and it is better to avoid and remain silent.

This is in line with the explanation above regarding the shift in the pattern of the ex-HTI da'wah struggle in Pasuruan. Before the Covid-19 pandemic and the ban on HTI organizations as legal entities by the government, the residence of Ust. Syamsudin is a halaqah place, but during the Covid 19 pandemic, some activities shifted

\footnotetext{
${ }^{43}$ Interview, Ust. Syamsudin, on 27 June 2021.

${ }^{44}$ Interview, Ust. Syamsudin, on 27 June 2021.

${ }^{45}$ Interview, Ust. Syamsudin, on 27 June 2021.
} 
to online. According to Ust. Syamsudin, in the Pasuran area, for example, the Taklim Council, has a lot, so there is no need to use other organizations to support the caliphate da'wah, such as institutions or houses of inspiration. The HTI diaspora in the Pasuruan city through educational institutions, such as SDIT before the ban, did not become a place and base camp, but it was more active after the ban. ${ }^{46}$ Obstacles that occur, even though preaching as much as possible and wearing a coat at a certain point, will smell and must be fighting. ${ }^{47}$

The understanding of the former HTI in Pasuruan related to local culture and the shari'a was also mentioned as part of the da'wah pattern, for example, Ust. Syamsudin explained that, after all, there is no problem with inculturation; the important thing is that it is by the Shari' $a$ because "the law must not change because of time and place". Furthermore, regarding local culture that is not or is not sharia, it does not matter, such as wearing Kemben, Batik, Wayang Kulit, Blangkonan and others. ${ }^{48}$ An important point extracted is that local culture can be implemented as long as it is not sharia. However, in the view of former HTI, for example, the view of Ust. Syamsudin's understanding of other shariah regarding hand cutting must be enforced for those who steal because it has been ordered in the Qur'an, ${ }^{49}$ such as QS. alMaidah: 38-39. It means:

(38) Men and women who steal cut off their hands as a recompense for what they have done and as a punishment from Allah. Allah is Mighty and Wise. (39) So whoever repents after doing injustice and corrects himself, Allah accepts his repentance. Verily Allah is Forgiving, Most Merciful.

According to him, this shari'a was also practised by the Prophet Muhammad, in contrast to liberal Islamic thought circles that "cut off the hand" for the perpetrator who steals has the meaning of majazi. According to the views of former HTI circles, for 1300 years, the caliphate underwent the law of cutting off hands, but there are rules, such as in times of famine, and there are limitations.

\footnotetext{
${ }^{46}$ Interview, Ust. Syamsudin, on 27 June 2021.

${ }^{47}$ Interview, Ust. Syamsudin, on 27 June 2021.

${ }^{48}$ Interview, Ust. Syamsudin, on 27 June 2021.

${ }^{49}$ Interview, Ust. Syamsudin, on 27 June 2021.
} 


\section{CONCLUSION}

In addition to utilizing the Al-Hamidy Al-Islamiyah Foundation, its also use the Bustanul Amilin Institute, the taklim assembly, "inspirational institutions/houses", SDIT as a medium for grounding the ideology of the caliphate. the strategy of struggle is to use the elders to use the Zoom media in preaching the caliphate, more than that, communication through personal contacts and Whatsapp continues, such as in Rembang more preaching their ideology to the kyai, and kyai who are pro-HTI in Rembang because the majority are ethnic Madurese, so they are very obedient. To the kyai, and the limited movement impacts the wisdom that is carried out more for internal strengthening. Opportunities and opportunities for HTI caliphate da'wah are that in-depth caliphate socialization is needed utilizing cadre halaqah and regular discussions during the online-based Covid-19 pandemic. On the other hand, the obstacle to proselytizing the ideology of HTI's caliphate in Pasuruan is that people only know the caliphate from the outside, a movement carried out from overt to clandestine, dealing with the authorities, NU and Banser.

\section{REFERENCES}

Abdurrahman, Ahmad Siddiq. "Strategi HTI Di Kota Makassar Pasca Pembubaran Oleh Pemerintah.” Universitas Islam Negeri Alauddin, 2019.

Aisyah, Siti. "Halaqah: Media Komunikasi, Publikasi Eksistensi Hizbut Tahrir Indonesia Sebelum Dan Pasca Pembubaran." Asyahid Journal Od Islamic and Quranic Studies (AJIQS) 1, no. 1 (2019).

Asmar, Afidatul. "Genealogi Dan Strategi Dakwah Kultural NU."

Islamica: Jurnal Studi Keislaman 13, no. 1 (2018): 164-83. https://doi.org/10.15642./islamica.2018.13.1.164-183.

Azmy, Ana Sabhana. "Fundamentalisme Islam: Telaah Terhadap Pemikiran Politik Hizbut Tahrir Indonesia (HTI)." Jurnal Wacana Politik 5, no. 1 (2020). https://doi.org/10.24198/jwp. v5i1.27997. 
Fitriayana, Siti Nur. "Fenomena Dakwah Eks-HTI Pasca Di Bubarkan." Islamic Comunication Journal 2, no. 2 (2019): 197-211.

Hasan, Nur, and Mochammad Parmudi. "Gerakan Sosial Keagamaan Dan Agenda Politik Kelompok Radikal Pasca Pemberlakuan Perpu No 2 Tahun 2017 Tentang Organisasi Masyarakat: Studi Kasus Hizbut Tahrir (HTI).” Semarang, 2018.

Hilmy, Masdar. "The Rise and Fall of 'Transnational' Islam in Indonesia: The Future of Hizbut Tahrir Indonesia (HTI)." In Rising Islamic Conservatism in Indonesia: Islamic Groups and Identity Politics, edited by Leonard C. Sebastian, Syafiq Hasyim, and Alexander R. Arifianto. London, New York: Routledge, 2021.

Lubis, Ali Akhbar Abaib Mas Rabbani. "Contestation On Political Space Between Islamism and Islamic Group in Presidential Election 2019." Al-Tahrir: Jurnal Pemikiran Islam 20, no. 2 (2020): 205-29. https://doi.org/10.21154/altahrir.v20i2.1932. Ruang Representasional." Al-Daulah: Jurnal Hukum Dan Perundangan Islam 10, no. 2 (2020): 222-50. https://doi. org/10.15642/ad.2020.10.2.222-250.

- "Pendidikan Islam Masa Umayyah Dan Indonesia: Seputar Perkembangan, Penggambaran, Dan Implementasi Pendidikan Islam Di Indonesia.” Medina-Te: Journal Studi Islam 16, no. 1 (2020).

- 'Rethinking the Book of Al-'Aql Al-Siyasi Al-'Arabi and Indonesian Political Phenomenon." Jurnal Penelitian 17, no. 1 (2020): 67-80. https://doi.org/10.28918/jupe.v17i1.2767.

Maksum, Ali. "Discourses on Islam and Democracy in Indonesia:

A Study on the Intellectual Debate between Liberal Islam Network (JIL) and Hizbut Tahrir Indonesia (HTI)." Journal of Indonesian Islam 11, no. 2 (2017): 405-22. https://doi. org/10.15642/JIIS.2017.11.2.405-422.

Milles, Matthews B., A. Michael Huberman, and Jhonny Saldana. Qualitative Data Analysis: A Methods Sourcebook. 3rd ed. Los 
Angeles, London, New Delhi, Singapore, Washington DC: Sage, 2014.

Muazaroh, Siti. "Pembubaran Hizbut Tahrir Indonesia (HTI) Perspektif Maqashid: Otoritas Atau Otoritarianisme.” Justicia Islamica: Jurnal Kajian Hukum Dan Sosial 16, no. 1 (2019): 103-20. https://doi.org/10.21154/justicia.v16i1.1622.

Ramadanti, Essi, and Hisbullah. "Eksistensi Dan Pola Perkaderan Pasca Pembubaran Hizbut Tahrir Indonesia." Siyasatuna 2, no. 2 (2020): 351-62.

Rizka, Ayu. "The Securitization of Hizbut Tahrir Indonesia.” Politik Indonesia: Indonesian Political Science 5, no. 2 (2020): 172 91. https://doi.org/10.15294/ipsr/v5i2.21712.

Rohmaniyah, Inayah. "Perpetuation of Radical Ideology: Depersonalization and Agency of Women After the Banning of Hizbut Tahrir Indonesia." Al-A 'raf: Jurnal Pemikiran Islam Dan Filsafat 17, no. 1 (2020): 45-66. https://doi.org/10.22515/ ajpif.v17i1.2361.

. "The Perpetuation of Identity and Symbolic Resistance of Hizbut Tahrir Indonesia After the Official Disbandment in 2017." Islamica: Jurnal Studi Keislaman 15, no. 2 (2021): 159 94. https://doi.org/10.15642/islamica.2021.15.2.159-194.

Sabri, Muhammad, Muh. Ikhsan, and Ismail Suardi Wekke. "Gejala Fundamentalisme Agama Di Indonesia: Membaca Hizbut Tahrir Indonesia Sebagai Gerakan Sosial.” INA-Rxiv 14 (2017). https://doi.org/10.31227/osf.io/a4mp7.

Udin, Muhammad Diak, and Abdul Muhid. "Komunikasi Getok Tular Dan Metode Dakwah Hizbut Tahrir Indonesia." Jurnal Komunikasi Islam 8, no. 2 (2018): 139-274. https://doi. org/10.15642/jki.2018.8.2.239-274.

Zulkarnain, Fisher. "The Political Thought and Movement of Hizbut Tahrir Indonesia (HTI)." Journal of Critical Reviews 7, no. 1 (2020): 478-82. https://doi.org/10.31838/jcr.07.01.94.

Undang-Undang Nomor 16 Tahun 2017 Tentang Tentang Penetapan Peraturan Pemerintah Pengganti Undang-Undang Nomor 2 
Tahun 2017 Tentang Perubahan Atas Undang-Undang Nomor 17 Tahun 2013 Tentang Organisasi Kemasyarakatan Menjadi Undang-Undang, Pasal 59 ayat (3) poin a, c, ayat (4) poin b, c. Interview, Ust. Syamsudin, on 27 June 2021, at 12:30. Interview, Ust. Syamsudin, on 27 June 2021, at 17:10

Interview, Ust. Syamsudin, on 29 June 2021, via whatsapp account media, at 15:05-15:20.

Adi Briantika, Ansor-Banser Gruduk HTI di Pasuruan dan Keduanya Sama-sama Keliru, pada hari Senin, 26 Agustus 2020, in https://amp.tirto.id/ansor-banser-gruduk-hti-di-pasuruan-dankeduanya-sama-sama-keliru-f1hC, accessed on 27 June 2021, at $14: 59$.

Fandi Armanto, Madrasah di Rembang Dilurug Banser, Diduga Jadi Tempat Kaderisasi HTI, 20 Agustus 2020, in https:// radarbromo.jawapos.com/headines/21/08/2020/madrasah-dirembang-dilurug-banser-diduga-jadi-tempat-kaderisasi-hti/ amp/, accessed on 28 June 2021, at 19:24.

Reporter Rizky Suryarandika, GP Ansor Teruskan Proses Hukum Terduga Pengikut HTI Pasuruan', pada hari Kamis, 27 Agustus 2020, in https://m.republika.co.id/amp/qfpudz396, accessed on 26 Juni 2021, at 18:54. 